\title{
Piketty comes to South Africa
}

\section{Fabio Andrés Díaz Pabón ${ }^{1,2}$ | Murray Leibbrandt ${ }^{1}$ (D) | Vimal Ranchhod $^{1}$ | Michael Savage ${ }^{3}$ (D)}

\author{
${ }^{1}$ Southern Africa Labour Development \\ Research Unit (SALDRU), African Centre of \\ Excellence for Inequality Research (ACEIR), \\ University of Cape Town, Cape Town, South \\ Africa \\ ${ }^{2}$ Department of Political and International \\ Studies, Rhodes University, Makhanda, \\ South Africa \\ ${ }^{3}$ International Inequalities Institute, London \\ School of Economics and Political Science, \\ London, UK

\section{Correspondence} \\ Murray Leibbrandt, Southern Africa Labour \\ Development Research Unit (SALDRU), \\ African Centre of Excellence for Inequality \\ Research (ACEIR), University of Cape Town, \\ Rondebosch, Cape Town, South Africa. \\ Email: Murray.Leibbrandt@uct.ac.za

\section{Funding information} \\ Economic and Social Research Council, \\ Grant/Award Number: ES/T004215/1; \\ Agence Française de Développement
}

\begin{abstract}
One of the most valuable features of Capital and Ideology is its concern to take history seriously and consider how the emergence of different political and economic regimes relate to discourses about fairness and justice across time. This paper pushes this agenda further by acknowledging that the experience of a few developed nations should not be taken as the template for the generalized study of inequality dynamics across time and space. In this paper, we interrogate Piketty's analysis and policy proposals against specificities that are central to understanding the production and reproduction of inequalities within South Africa. We reflect on the South African case, the structure of inequality and its changes since 1994. We review a battery of policy interventions that have been implemented to address inequality in the last 25 years. We emphasize that the long shadow cast by centuries of colonialism and various forms of apartheid strongly affirm Piketty's emphasis on understanding history. But this is both affirmation and critique given the foundational, imbedded impact that this specific legacy has had on post-apartheid society and its policies. Piketty is aware that the levels of inequality in South Africa are so high that this is "unknown territory." We map out some of this territory to reveal how these extreme initial wealth and racial inequities inform the reproduction of inequalities in all dimensions and undermine well intentioned policies. We claim that understanding extractive histories, imbedded wealth inequalities, and complex social and political institutions allows us to understand and confront some of
\end{abstract}


the reasons why even in light of progressive policies, many of which are in line with the proposals from Piketty, government interventions have thus far failed to reduce inequality.

KEYWORDS

Africa, inequality, policy making, South Africa

\section{1 | INTRODUCTION}

One of the most valuable features of Capital and Ideology is that it takes history seriously and considers how the emergence of different political and economic regimes relate to discourses about fairness and justice across time. Piketty's warning about how the experience of a few developed nations should not be taken as the template for the generalized study of inequality dynamics across time and space is a vital message for researchers and scholars; this message is also an invitation to connect with a large literature on inequality that has been produced over the past 30 years by development economists, anthropologists, and sociologists.

And yet, writing from Cape Town, South Africa, and as members of the recently established African Centre for Excellence in Inequality Research (ACEIR), we are struck by how limited the treatment of the African experience remains. Only three pages (693-696) focus on Africa, as part of a (very important) discussion of the "pauperization of poor states." South Africa does get more specific attention, because of the distinctive role of apartheid, and because of the very high levels of income inequality which have sadly made it one of the most unequal countries in the world, but nonetheless this discussion remains a minor part of the book's coverage.

Let us be clear, we have no intention of playing the familiar academic game of moaning about gaps and lacunae, as if we are not getting our fair share of pudding at the dinner table. It is far more important to take the opportunity of reflecting about how the South African experience can bear on the issues that Piketty raises about the return of inequality, and possible strategies to tackle inequalities.

We welcome the way that debates on inequality have become more global and acknowledge that numerous factors, including problems with data, explain the absence of analysis of other African cases, but note the continued downplaying of African experiences. While we do not see the South African case speaking on behalf of the continent, we will use its lessons and experiences of policies implemented to deal with inequality as contributing toward a better discussion about African experiences in dealing with inequality.

To do this, in the next section we introduce Piketty's more recent work considering its contribution to recent literature in the study of inequality. In the third section, we introduce key inequality trends and dynamics in South Africa. This leads to our fourth section where we describe to assess the policy interventions that have been implemented to address inequality in South Africa. This informs our reflection, in section five, about the resilience of categorical inequalities in South Africa, and how a profiling of such categorical inequalities in any context can usefully augment Piketty's imperative to forge egalitarian coalitions nationally and internationally with a grounded analysis of prevailing social structures. In the concluding section, we build on this analysis by reflecting on the interaction between the local and international forces conditioning the political economy of post-apartheid South African as an important point of engagement for understanding the success or failure of policy proposals aimed to reduce inequality.

\section{2 | THE STUDY OF INEQUALITY AND PIKETTY'S CONTRIBUTIONS}

Before we reflect on the importance of African experiences in relation to the recent revival of the economic analysis of inequality, it is helpful to reflect on more recent inequality research, along with a "spectre" which 
increasingly haunts the recent inequality debate. The recent mainstreaming of the study of inequality in economics was initially informed by the study of the United States, and notably the demonstration of the staggering increase in the fortunes of the top percentiles of the income distribution since the 1980s. This idea was initially inspired by Krugman and Venables (1995), with Piketty and Saez's (2003) paper soon becoming the crucial reference point. Such research was supported by the extension of the comparative focus to include other OECD nations, most of these being in Europe. This extension is illustrated by Atkinson and Piketty's (2007) edited collection, is also strongly represented in Piketty's Capital in the 21st Century and also, in a different register, in Wilkinson and Pickett's (2010) The Spirit Level. Here, the focus becomes more around the fact that the rise of income inequality is much less marked in many European nations, and, therefore, that inequality is not inexorable.

Most recent research on inequality has been led by Branko Milanovic's (2016) analysis of global inequality, as encapsulated in his famous "elephant graph." In fact, Milanovic's analysis drew on long standing debates within development studies over inequality, growth, and development (Stewart, 2016) and more recent work by Bourguignon (2017) and others which pointed to the decline of "between nation" inequality, even at the same time that "within nation" inequality was often (though not always) on the rise. This more optimistic interpretation was boosted by evidence from some parts of the world, especially in South America, which pointed to cases of inequality decline in the early 2000s (see Lustig et al. (2012) and the discussion in Simson and Savage (2020)).

Milanovic and others offered a far less gloomy picture of inequality trends, which emphasized how for many people in the global south, recent decades had seen an historically unprecedented rise in living standards before the COVID-19 pandemic. His work has become a foil for the recent work of Piketty and his collaborators. They largely accept the gist of Milanovic's elephant graph with a crucial caveat; because those in the global south started from a place where they earned such low incomes, their relative increases are dwarfed in absolute terms by the burgeoning fortunes of the global 1 percent. In their analysis (Alvaredo, 2018), found that the highest paid $1 \%$ of earners in the world took an astonishing $27 \%$ of the globe's overall increase in earnings between 1980 and 2016.

Here, we need to make our first substantial point regarding the African experience. Africa as a whole has not seen a dramatic rise of inequality (Chancel et al., 2019). Yet, the trends in inequality across Africa are remarkably varied as illustrated by Beegle et al. (2016, p. 125) and Odusola et al. (2017, p. viii). Outside of southern Africa, most African countries have a Gini coefficient below 0.5 , and there is also variation in the trends in inequality. Simson and Savage (2020) identify Mali, Guinea, Burkina Faso, Niger, and Mauritania as experiencing declines in their Gini coefficients between the early 1990s and 2010. This might be a further reason why the African experience has not figured centrally-unlike the American, European, Chinese, and South American cases-in a global analysis of inequality dynamics, the trends of the continent are not easily generalizable.

Yet, the continent is home to areas of extremely high inequities. As measured by the Gini coefficient, 10 of the 19 most unequal countries in the world are from Sub-Saharan Africa (SSA) (Odusola et al., 2017). Thus, if these country coefficients are averaged, SSA sits alongside Latin America as the most unequal territory in the world. Southern Africa is the highest inequality sub-region with most of these countries having Gini coefficients above 0.6. Indeed, five of the world's top 10 most unequal countries, including South Africa, are from southern Africa.

At this point, let us reflect on Piketty's "spectre" which also haunts the inequality debate. In Capital in the 21st Century, Piketty famously introduces his "fundamental laws of capitalism," most famously that $r>g$, that is, that the return to capital exceeds the growth rate. In Capital and Ideology reference to fundamental laws of capitalism are dropped, and the need for local and contextual understandings of what policies should be implemented is emphasized, but the focus on wealth and property as an overarching force which tends to accumulate unless checked is a very strong feature. The point of this "spectre" is that it presents a much darker picture of the capacity of governments to address inequality and depicts inequality as having much more inertia than is evident from exponents of previous scholarship. For scholars such as Atkinson, there was reason to be optimistic that effective national level policies, linked to international co-ordination, could in fact lead to the management and diminution 
of inequality (Atkinson, 2014). For other scholars such as Milanovic, the different forces influencing an economy allied to technological advance might also be expected to reduce inequality at the global level. ${ }^{1}$

However, Piketty himself seems to oscillate between these more positive and optimistic views, and a bleaker perspective informed by the "spectre" of wealth and property. Capital and Ideology is riddled with the insistence that we can address inequality with the right kind of politics supporting "a participatory socialism" which challenges the jurisdiction of private property. However, it is not always clear if this is in keeping with the spectres which also hover over his work. Indeed, he has made this very clear during a lecture he delivered in South Africa in 2015 and emphasized how even the experience of the French revolution did not see the fundamental shift that some of its champions wished for. The difference between the claims of French elites that were asserting "we're all equal now," while making no real progress in addressing inequality until the first world war resonates with the case of South Africa (Scheidel, 2018).

It is noteworthy that Capital and Ideology veers regularly between the idea that well-designed policy interventions can make a difference, and the altogether gloomier spectre that inequality is such a pervasive force that even well intentioned policies to tackle it often fail to hit the mark. A central aspect of this dilemma is the extent to which inequality is driven by forces outside the control of national governments and well-intentioned policymakers. Piketty is entirely alive to the significance of global flows of capital, and indeed makes the vital point that the offshoring of wealth in Africa is at an extremely high and damaging level (2020, p. 695). But these points are not followed through into a systematic global political economy which is necessary.

Here, the South African case illustrates that there is a major gap in the historical and more contemporary aspects of Piketty's analysis. The South African case in fact illustrates; (1) how well-intentioned policies fail to reduce inequality, (2) how the forces of a global political economy condition the feasible space for policies to be implemented, and 3. how ideology is co-created by local and international factors.

One of the most valuable features of Piketty's analysis of the 19th century, is the discussion of the central role of slavery and colonial relations in shaping inequality regimes. He shows very convincingly how the development of "ownership societies" in 19th century Europe, based on the primacy of private property and the accumulation this generates, are directly associated with the role of slavery. He also brings out very powerfully how "colonial societies rank among the most inegalitarian ever seen" (table 7.4). However, the long-term significance of these colonial relations and the legacies of imperial relations in conditioning contemporary inequalities contrasts with the assumption that once decolonization or liberation takes place, nations have the scope to set their own agendas. Even though he recognizes that these new independent nations were constrained by the liberalization of trade imposed by rich countries, there is a lack of focus on the interaction between long-term colonial relations, the legacy of categorical inequities imposed by colonial models of state, and how these factors continue to shape postcolonial regimes after they become independent.

Another dimension along which Piketty's analysis can be enriched by the South African analysis is the tension between the institutional vis-a-vis noninstitutional mechanisms that condition the existence of inequality. Whereas Piketty discusses how ideologies relate to the political arrangements and laws related to property, rights, and inequality, ${ }^{2}$ the evidence from the case of South Africa illustrates how the reproduction of inequality takes place in spite of the existence of new ideologies and legal mandates under which the reduction of inequities is a goal of a state, while inequality prevails in spite of different policies and programs.

The South African experience remains historically very distinctive to other African countries. Moreover, during the British empire, it had a much larger share of White settlers than any other African nation. Piketty valuably shows (p. 256) that while there were never more than a tiny share of Europeans in India, considerably more in North Africa (4\% in Morocco; $8 \%$ in Tunisia; and more than 10\% in Algeria), with equivalent status to Britain itself. This concern to establish autonomous polities on behalf of White settlers, therefore, went alongside brutal racism directed against indigenous people, as the South African experience has demonstrated very powerfully. Nonetheless, the case of South Africa provides an interesting case to reflect about the way in which long-term historical forces of colonialism continue to exert a powerful hold in defining inequities which needs to be factored 
into an understanding of the contemporary situation in different African contexts, and can help in explaining the prevalence of inequality despite government interventions that could potentially reduce different inequities. For this reason, in the next section we reflect on the evolution of inequality of incomes within South Africa over recent decades, and especially since the end of the apartheid regime. Here, we pick up on the significance of long-term historical forces which continue to exert a powerful hold on present day realities.

\section{ECONOMIC INEQUALITY IN SOUTH AFRICA}

To dovetail with Piketty's focus, we begin by focusing on trends in income inequality in South Africa before broadening out to other expressions of inequality such as wealth inequality. We do this relying on earlier work by Leibbrandt et al. (2010), and Hundenborn et al. (2018) who use household surveys from 1993, 2008 , and 2014 to describe the levels and changes in income inequality over the period. As alluded to earlier, post-apartheid South Africa was launched off a history that left it with a Gini coefficient of incomes of 0.68 , in competition with Brazil for the highest measured income inequality in the world. This income inequality has not fallen over the postapartheid era, appearing to rise somewhat up to 2000 before falling back to around its starting level by 2014 . This pattern is also illustrated by other sources such as Statistics South Africa ${ }^{3}$ (2019). South Africa is a society that generates extreme inequality. As Piketty himself argued in 2015:

[T] he share of total income going to the top $10 \%$ of earners in South Africa currently, right now, is between $60 \%$ and $65 \%$ of total income for the top 10\%. For Brazil, just to make a comparison, we are between 55\% and 50\% and in most European countries [is] between 30\% and 35\% [...] South Africa is really at the top of the class, so to speak, and is in a way, way out of the experience that we can think of.

(Piketty, 2015)

But this very high and persistent level of national income inequality should not be taken to imply ossification and that income inequalities have been constant. One of the best illustrations of this is the decomposition of income inequality along racial categories to analyze intra-group and between group inequalities. Leibbrandt et al. (2010) undertook this decomposition for 1993-2008. For 1993, they show an astonishing contribution of between group inequality of $42 \%$ and $50 \%$, depending on whether racial population shares or income shares are used to weight inequality. Usually this between group contribution lies below 10\% (Bhorat et al., 2001). By 2008 the inequality between different groups had declined slightly, to 30\% and 38\%, respectively, for the two weightings. Hino et al. (2019) suggest a further decline by 2015.

It bears reiterating that the most shocking feature of the analysis of horizontal inequalities is how salient the racial categories imposed by apartheid are and how incredibly high they remain. Moreover, one of the key factors driving their relative decline is that within group inequality has increased in absolute terms more sharply than between group inequality has declined, thus lowering the relative contribution of between race inequality. Indeed, the ratio of mean incomes for Black and White South Africans rose only very marginally from $12 \%$ to $13 \%$ between 1993 and 2008 and the ratio of median incomes actually fell (Leibbrandt et al., 2012). Thus, although the post-apartheid era has seen the increasing importance of within group inequalities, this should not be seen as approximating a substantial overlapping of the upper half of the Black South Africans with the upper half of the White South Africans distribution of incomes. It reflects a tepid overlapping of the upper and lower tails of these different distributions, as displayed in Figure 1.

Another useful income inequality decomposition is one that examines the contribution of the components or sources of income to income inequality. In South Africa, the most important components of household income are labor market income, government grants, remittances, and investment income (see the review in Leibbrandt 


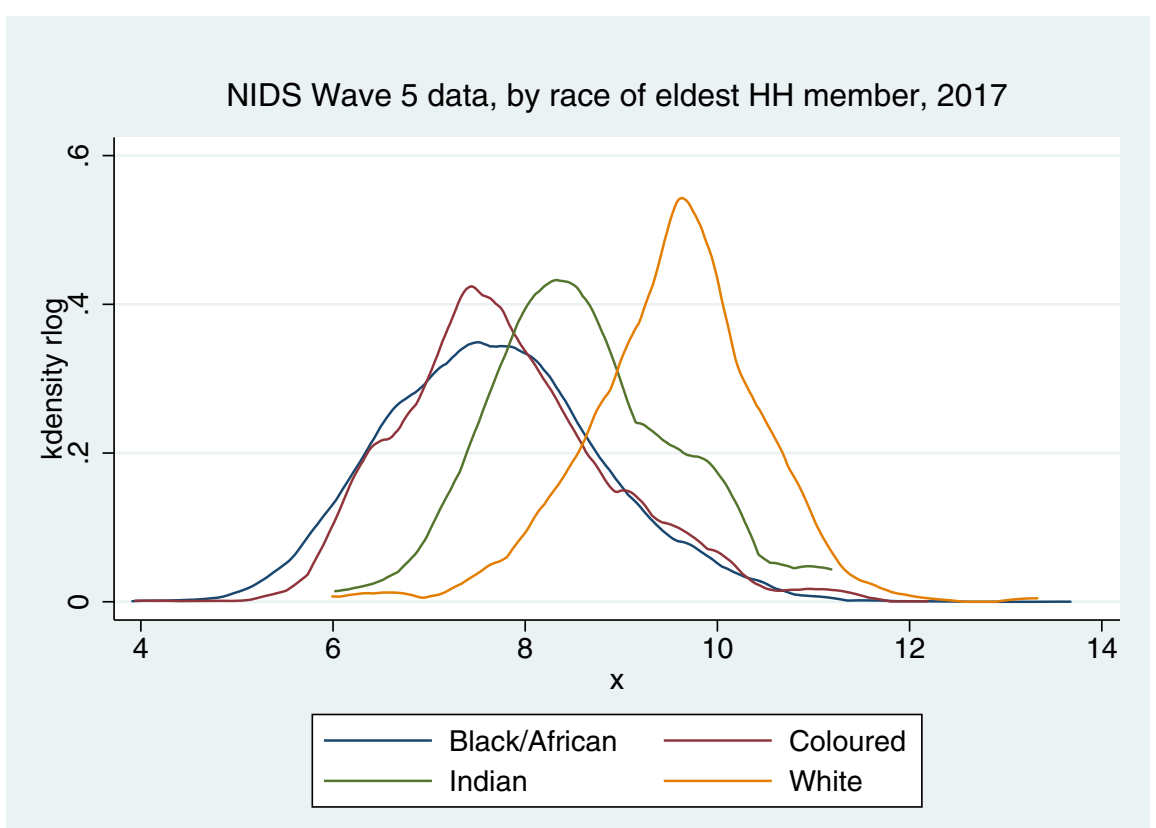

FIGURE 1 Kernel density plot of the logarithm of household per capita income by race (eldest household member) according to NIDS Wave 5 data. Source: Own calculations [Colour figure can be viewed at wileyonlinelibrary.com]

et al. (2012)). Most recently Hundenborn et al. (2018) replicates these exercises for 1993, 2008, and 2014; and affirms that in 1993 and 2014, labor market income accounted for $84 \%$ and $90 \%$ of the overall income Gini coefficient, respectively. Government grants are the second largest component, but it is inequality dampening.

Bassier and Woolard's (2018) recent analysis of tax and household survey data are a striking demonstration of the extent of "top end" inequality in South Africa. Whereas Credit Suisse in 2016 estimated that there were about 45,000 USD millionaires in the country, Bassier and Woolard (2018) put the number much higher, at about 182,000 . They also make two critical points about recent income dynamics and the relationships between income sources. ${ }^{4}$ First, between 2003 and 2015 , nearly $60 \%$ of the population earned zero taxable income. ${ }^{5}$ Over the same period, the real incomes of the top $5 \%$ of income earners increased by $5.1 \%$ per annum. Second, the growth in real incomes of the top 5\% was more than double the rate of growth of gross national income (GNI) after the 2008-09 recession. In contrast, the incomes of the other $95 \%$ either stagnated, or, in the case of the bottom of the distribution, showed only slight growth. This explains why real incomes of the top $1 \%$ almost doubled between 2003 and 2016, and how between 2010 and 2016, the income shares of the top 1\% increased from 10.5\% to $12.6 \%$ of the country's GNI.

In addition, the top percentile in the income distribution ${ }^{6}$ has a much higher wealth to income ratio than the rest of the earnings distribution. Income from sources other than salaries, particularly capital, increases rapidly in the top two percentiles. This is compounded by labor market dynamics in which highly skilled professionals at the top end of the income distribution have more bargaining power as they are not easily replaced. In addition to this, technical changes in the economy may further favor this group and explains the increase in income differentials. This is especially interesting given its resonance with the argument made by Piketty (2014) that inequality increases when the rate of return to capital is greater than the rate of economic growth.

This work by Bassier and Woolard further reveals the importance of income flows from wealth and the benefits that flow from wealth-Piketty's inequality "spectre." Orthofer's (2016) research showed that the capacity to pass on wealth from one generation to another is critical to maintaining high living standards in times of 
unemployment or throughout retirement and thus explains the trends in income inequities. The South African income Gini coefficient is around 0.67, while for wealth it is at least 0.9-0.95. Both of these values are higher than in any other major economy for which such data exist in the world. Using tax records and data from the National Income Dynamics Study (NIDS), she estimates that the wealthiest $10 \%$ of the population own at least $90 \%-95 \%$ of all wealth, whereas the top $10 \%$ in the income distribution receive a smaller proportion (55\%-60\%) of all income. The middle $40 \%$ of the wealth distribution is almost as asset-poor as the bottom $50 \%$.

Despite its importance in understanding inequality dynamics, South Africa has paid little attention to assembling and analyzing reliable wealth data. Chatterjee et al. (2020) take stock of wealth data by triangulating the survey data and tax data used by Orthofer with national accounts data, to derive the best possible estimates of the distribution of personal wealth given current data. Even after recognizing that these data might underestimate the value of capital, they find that South Africa has "unparalleled" levels of wealth concentration that are even higher than what Orthofer found:

The top 10 per cent own 86 per cent of aggregate wealth, and the top 0.1 per cent close to onethird of aggregate wealth. The top 0.01 per cent of the distribution (3,500 individuals) own 15 per cent of household net worth, more than the bottom 90 per cent as a whole. Such high levels of inequality can be accounted for in all forms of assets, including housing, pension funds, and other financial assets. Our series show no sign of decreasing wealth inequality since apartheid; if anything, we find that inequality has remained broadly stable and has even slightly increased within top wealth groups.

(Chatterjee et al., 2020, p. 2)

The attention that we have given to the assets and wealth at the top end of the income distribution should not detract from analyzing other sources of inequality such as the labor market. Alongside its status as the one of the highest income inequality countries in the world, South Africa also has the one of the highest earnings inequalities in the world. Finn and Leibbrandt (2018) show that, while from 2001 to 2014, average real gross earnings of workers rose from ZAR 5,740 to ZAR 7,951 per month, real wage increases went mostly to top earners as overall inequality increased. ${ }^{7}$ As measured by the Gini coefficient, earnings inequality increased from 0.552 to 0.634 between 2001 and 2014. Such extreme earnings differentials are entrenched in the salary and wage structures in the formal economy. Statistics South Africa (2019) indicate a segmented labor market along racial categories, coupled with large power and class disparities between employers and employees in a job-scarce economy. Indeed, this earnings inequality does not include the unemployed "zero-earners"; as the unemployment rate has risen from just over 20\% to $30 \%$ over the last decade and it is overwhelmingly Black South Africans who bear this burden.

Figure 2 (from Statistics of South Africa (2019) illustrates the real earnings of employed people at various percentiles of the earnings distribution are plotted against time for the period from 2011 to 2015. The compression of low wage earners close to the horizontal axis somewhat hides the fact that for low wage earners and median earners, the value of their earnings decreased after accounting for inflation. Relatively high wage earners, that is, those at the 90th percentile, maintained parity with inflation. It is only for the very top end of the labor market that we observe actual growth in real earnings, of $15 \%$ and $48 \%$ for the 98 th and 99 th percentiles, respectively. Taken together, this indicates a substantial widening of the gap in the earnings distribution in the period following the 2008 global financial crisis.

The reproduction of intergenerational inequality and poverty is associated with the well documented unequal assets, notably education, health, and housing (Pellicer et al. 2011; Pellicer \& Ranchod, 2016; the Mandela Initiative, 2018; Lundberg \& Startz, 1998; Spaull \& Jansen 2019). Piraino (2015) reveals an estimate of an intergenerational earnings elasticity of between 0.62 and 0.67 , finding that it is a limited set of inherited circumstances and especially racial categories that explains this persistence. International comparisons undertaken by Narayan et al. (2018) make it clear that this is an extremely high correlation by international standards. In nearly all high-income 


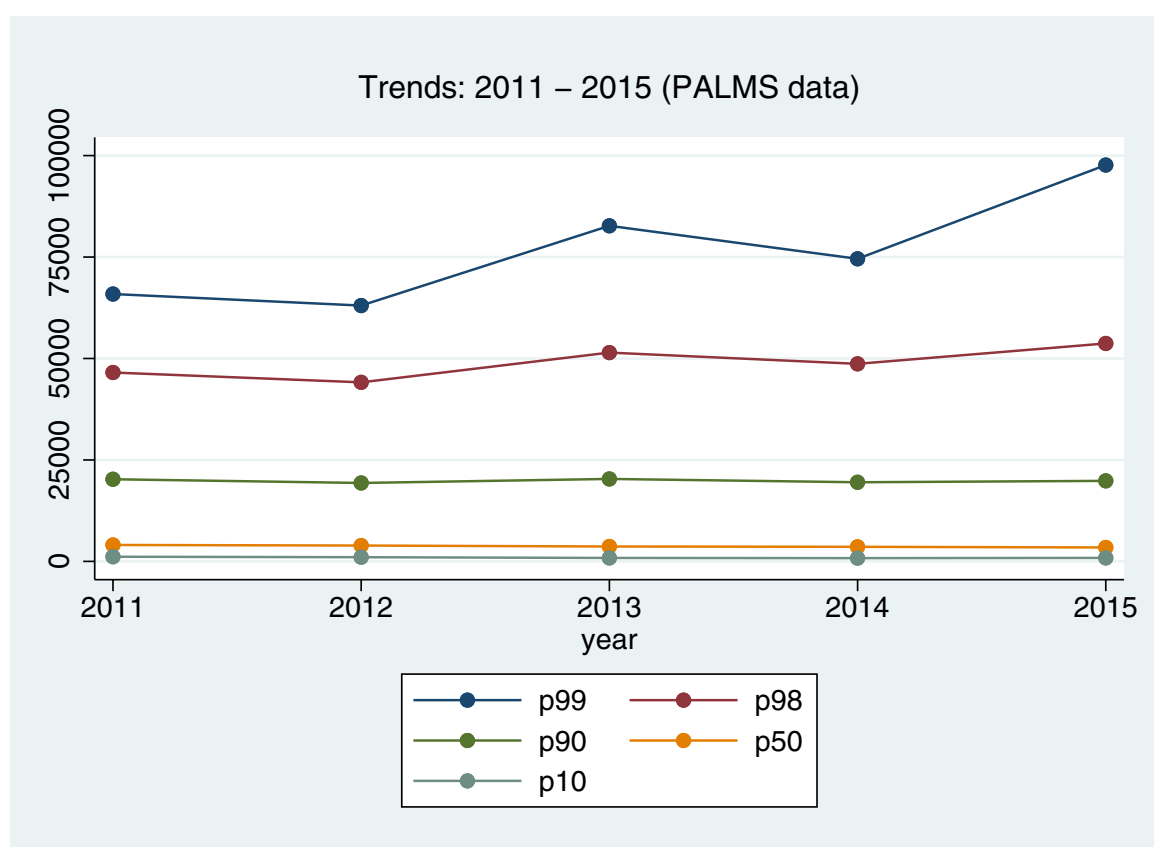

FIG URE 2 Percentiles of real earnings per month between 2011 and 2015 according to PALMS data. Source: Own calculations. Figure 4.3.6 of Inequality Trends Report, StatsSA (2019) [Colour figure can be viewed at wileyonlinelibrary.com]

countries this estimate is below 0.4 and, only in a few high inequality middle income countries is it above 0.6. with the South African estimates being at the upper end. Finn et al. (2016) confirm this very low earnings mobility across generations in contemporary South Africa and show that this immobility is particularly strong for those at the bottom and the top of the earnings distribution. If parents are at the bottom of the earnings distribution, their children have a $95 \%$ chance of being there too, whereas children of parents who are placed in the top deciles of the earnings distribution have a similar likelihood of being in the top deciles of the earnings distribution as well.

This illustrates why South Africa's intra-generational inequality has remained persistent. Indeed, Schotte et al. (2018) show that, over the past decade, progress toward social mobility has slowed and even stalled. While Statistics South Africa estimates that, in $2015,55 \%$ of the population lived in poverty ${ }^{8}$ (Statistics South Africa, 2019). Schotte et al. estimate that about $49 \%$ of South Africans live in chronic, persistent poverty. In addition, another $11.4 \%$ can be classified as "transient poor," and about $19 \%$ are part of a "vulnerable middle class." Both groups (transient poor and vulnerable middle class) are at risk of falling back into poverty from 1 year to the next, thus illustrating that dynamic poverty is much more pervasive than static measures of poverty indicate. Even preceding the COVID-19 pandemic, socio-economic life was characterized by precariousness and vulnerability for three quarters of South Africans.

These inequality dynamics perpetuate the racial imprint of apartheid. For the citizens classified as White (less than $9 \%$ of the current population), 93.6\% are consistently non-poor in five interviews between 2008 and 2017. In contrast, for the citizens classified as Black, only about $9 \%$ of them ( $80 \%$ of the population) were consistently non-poor and about $63 \%$ were poor in four out of five instances or every instance. All in all, White South Africans continue to have better access to opportunities in relation to health, incomes, employment, education, and living conditions; which enables them to develop capacities that serve to maintain their privileged positions in South Africa. While the share of White people is less than $10 \%$ of the overall population, almost three-quarters of the highest earners in the country are White. 
This section has detailed the deep hold of socio-economic inequity in South Africa. Even today, inequalities pervade almost every aspect of this daily life. Predominantly, livelihoods and opportunities are bound by racial categories, as people still live in racially divided areas that correlates with highly unequal housing, public services, transport, schools, employment, safety, and opportunities. These outcomes remain even though there have been a series of initiatives that have aimed to reduce inequality in South Africa after the end of apartheid.

\section{4 | THE EFFECTIVENESS OF POLICIES TO TACKLE INEQUALITY IN SOUTH AFRICA}

In the context of the deep hold of inequality in South Africa, we are struck by the evidence of the extent to which well-intentioned, even radical policies that have been proposed by Piketty have been already proposed and implemented in South Africa. This not only illustrates that such policies have been designed and implemented in response to different understandings of fairness and social justice, but also illustrates how difficult it has been for policies to have substantial impact in this inequality regime.

Starting with the Reconstruction and Development Programme (RDP) in 1994, all policy documents have consistently spoken about the need to reduce inequality and have given the state a strong role in redressing the social, political, economic, and spatial disadvantages. Whereas the discursive focus on inequality has been explicit, the actual attention to inequality (versus. poverty) and the coherence of the strategies to address inequality remains debatable (Bond, 2014). Nonetheless, these policies can be seen as resonating with some of Piketty's proposals about the need for opportunities and access for the citizenry and can in fact illustrate the practice of such policies.

Below we discuss some of the policies implemented in South Africa since 1994, distinguishing between policies aiming to reduce inequalities in the country operating across three vectors of intervention: (1) Policies taking place within the existing structure of the economy, (2) Policies aiming to nudge the direction the economy, and (3) Policies that aim to change the structure of ownership in the economy.

\subsection{Policies aiming to reduce inequality within the current structure of the economy}

A number of policies have been implemented post-1994 that have potentially shaped the evolution of incomes without substantially changing the way in which the economy operates. These include labor market policies, including minimum wages, taxes, and cash transfer systems.

The labor market was, and still is, the dominant contributor to income inequality, and thus remains an important driver of inequality in South Africa (Bassier \& Woolard, 2018). Labor market reforms instituted in the 1990s included the Basic Conditions Employment Act (BCEA) of 1997, that defined minimum conditions of employment for all sectors, and the Labour Relations Act (LRA) of 1995, that formalized sectoral-level bargaining processes between unions and workers. The LRA is an example of guaranteeing workers the right to organize and unionize, and governs issues such as collective bargaining, the right to strike, and processes for resolving labor disputes. These regulatory frameworks provided a structure for the legal protection of workers and the support of power asymmetries of employees relative to employers.

In addition, regulations concerning minimum wages impacted the wages of the lowest paid workers. At the end of apartheid, minimum wages were not nationally set, but were industry, occupation, and sometimes regionally determined. For all workers employed in sectors covered by the LRA these processes were implemented annually through the LRA, by sector. For workers in sectors such as domestic work or agriculture that were not covered by the LRA, the Employment Conditions Commission made sectoral determinations that set minimum wages for each of these sectors. These sectoral minima were signed into law by the Minister of Labour, and at some point, there were nine different sectoral minimum wages in effect. 
Yet, these measures raise questions about the impact of improving the lower bounds for wages and how they can reduce inequality. Some large sectors in terms of the number of people employed that also typically earn low wages include domestic work and agriculture. The evidence illustrates that legislation was effective in raising the wages of these low wage earners significantly, despite considerable levels of non-compliance (See Dinkelman and Ranchhod (2012), and Bhorat et al. (2014)), yet only having a limited impact in terms of reducing inequality of incomes.

For the first time ever, a single national minimum wage was established with effect from January 2019. This set a national wage floor and effectively replaced all the sectoral determinations for uncovered workers. However, the Bargaining Councils in covered sectors can, and generally do, establish substantially higher sectoral minima for their constituencies. While these measures are promising, the establishment of a cautiously set national minimum wage is unlikely to have a substantial impact on the inequality of incomes. As minimum wages set the income floor and as the trend in inequality of incomes in South Africa is driven by the impact of a small number of very high earners, the improvements in minimum wage levels do not directly impact the largest driving force in the inequality of incomes. Yet, this does not deny the importance of minimum wages as part of the policy package and the need for a policy and societal commitment to tackle inequality by devoting explicit attention to the vulnerable in the labor market and in society more generally. ${ }^{9}$

Two other major policy levers used by South Africa with the potential of changing the distribution of disposable incomes have been taxes and transfers. Over the post-apartheid era South Africa has designed and funded a large unconditional cash transfer system (Woolard \& Leibbrandt, 2013). These disbursements are perhaps the most effective tool that South Africa has had in reducing the increase of inequality in South Africa (see Figure 3). This is due to its effective targeting, as the poorer $50 \%$ of the population get more than $70 \%$ of the total direct cash transfers (Mashekwa \& Woolard, 2018, p. 10). The impact of these grants is also explained by the expansion of the grant system as the coverage of grants such as the child support grant and the state old pension grant has increased, thereby reaching a greater proportion of citizens in a condition of vulnerability. It is estimated that social grants reach out to a population of more than 17 million out of a population of 57 million inhabitants. The

\section{Concentration curves for direct transfers}

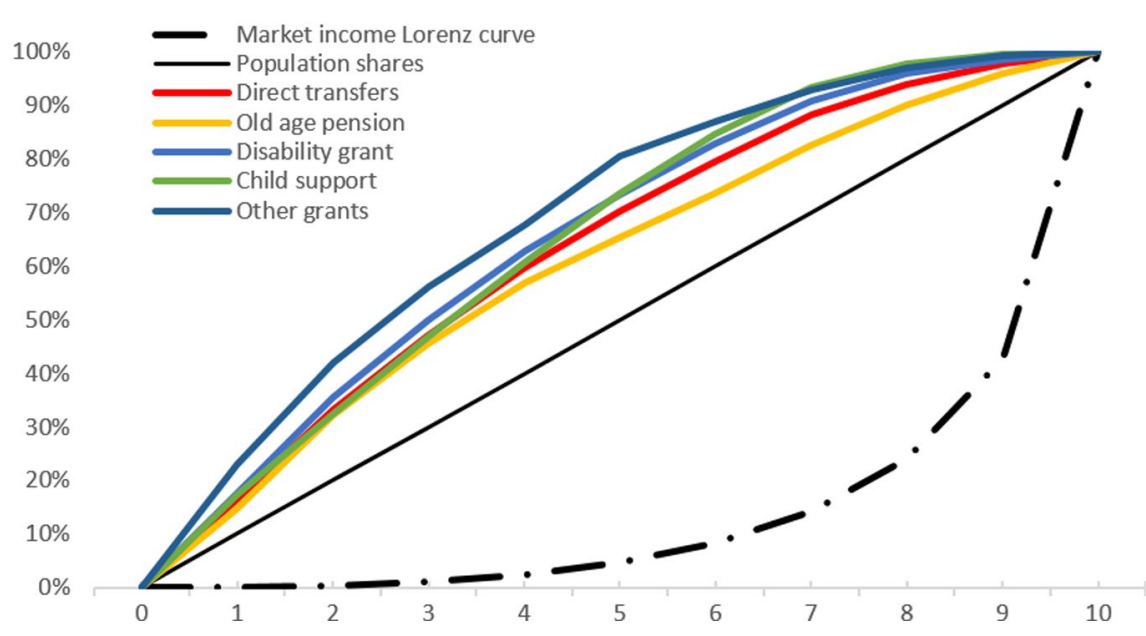

FIGURE 3 Representation of the impact of different grants on reducing the level of inequality in South Africa as represented by Lorenz curves. Source: (Mashekwa \& Woolard, 2018, p. 10) [Colour figure can be viewed at wileyonlinelibrary.com] 
most recent evidence indicates that grants have had a substantial dampening effect on the increase in inequality (Hundenborn et al., 2018).

Like cash transfers, income tax policy in South Africa is generally progressive (Mashekwa \& Woolard, 2018, p. 2). The top $20 \%$ of salary earners account for $77 \%$ of total taxable incomes and represent $90 \%$ of direct taxes of the country (Inchauste et al., 2015), making income taxes progressive. Indirect taxes such as the value-added tax and fuel levies are increasingly important but are much less progressive. While there is some discussion about increasing the progressivity of income taxes, the vast disparities of wealth that were detailed earlier and South Africa's underdeveloped wealth taxes have made this the focus of current debates (Chatterjee et al., 2020). There seems to be much scope for exploring stronger wealth taxes, especially the taxation of inheritance.

\subsection{Policies aiming to nudge the direction of the economy}

In addition to policies that aim to directly address inequality through improving minimum wages, taxes and transfers, there have been many other policies that were targeted at changing the distribution of endowments that affect income. We discuss a few of these, including guaranteed employment schemes, housing policy, and market regulatory bodies.

In addition to multiple educational interventions, the South African government has implemented a number of different state employment programs to directly reduce unemployment, with the two larger programs being the Community Works Programme (CWP) and the Expanded Public Works Programme (EPWP). Since 2012/13, according to the South African government, the EPWP has created over four million "work opportunities" (South African Government, 2019). Despite the extent and the budget allocated to the program, there are questions about the results of the program in improving sustainable employment and reducing income inequality. Given the generally poor labor market conditions, it is not surprising that beneficiaries of these programs have reported the remaining challenge of accessing permanent employment (Hlatshwayo, 2017). The assumption that improvement in the supply of labor and training would be enough to change the labor market ignores the structures that create a bimodal job market (Altman et al., 2004, p. vii).

A different intervention, which does not have a direct impact through the labor market, has been a substantial housing policy. Housing in South Africa is conceived of as a way to make assets accessible to citizens and thus reduce inequities, as housing is envisioned as a way in which wealth could be consolidated or formalized. The South African government has aimed to improve housing and fulfill the right to housing for its citizens via different programs aimed at correcting the spatial inequities related to housing. ${ }^{10}$ According to Statistics South Africa by 2017, $13.6 \%$ of South Africans lived in state subsidized housing. This illustrates the significant efforts by the state that has managed to build 3 million houses between 1994 and 2015 (Southern African Catholic Bishops' Conference, 2017). Nevertheless, the backlog in housing has also increased from 2.1 million houses in 1994 to 2.3 million houses in 2014 (Sisulu, 2014). Housing programs have also inadvertently reproduced the preexisting patterns of spatial segregation (Southern African Catholic Bishops' Conference, 2017). Capital investment undertaken by the government has mostly benefited the financial sector (Bond, 2014) and furthermore homeownership can actually increase marginalization due to the financial burden of homeowners as found by research from Lemanski (2017, p. 8) and Daniels (2001).

In addition to policies that impact directly on individuals, South Africa also created new regulatory bodies that can countervail power asymmetries. Examples of these are institutions include the Competition Tribunal, the Competition Appeal court, and the Competition Commission. To date, these tribunals have had only limited success in affecting inequality, although it should be noted that this was not their explicit mandate. The continuing existence of high market concentration and collusion illustrates that the control of markets and prices remains in the hands of a limited number of individuals or organizations, with the end result that some companies still manage to evade, bypass or ignore the decisions from regulators (Hawthorne et al., 2014). 
Importantly, the regulation of markets and institutions is not the only way that countervailing forces operate in South Africa. Several market failures have been subject to the response from social mobilization by civil society and social movements (Ballard et al., 2015), and in some cases these groups have been able to pressure the government to address particular inequities, as in the case of the HIV/AIDS pandemic.

\subsection{Policies aiming to change the structure of ownership in the economy}

There have also been some attempts to more fundamentally change the structure of ownership in the economy via more ambitious redistribution policies that could be seen as part of "participatory" socialism initiatives. The two most prominent in this group are affirmative action policies and land redistribution policies.

Black Economic Empowerment (BEE) and then, Broad-Based Black Economic Empowerment (BB-BEE) policies have aimed to redress racial and gender inequalities by facilitating the participation of Black ${ }^{11}$ South Africans in the economy (Department of Planning, Monitoring, and Evaluation (DPME), 2019). These policies are aimed at increasing the opportunities, the skills, and the welfare of Black workers (Acemoglu et al., 2007), improving basic conditions and employment equity to advance affirmative action in the workplace, facilitating skills development, and shifting enterprise ownership toward Black South Africans (Department of Planning, Monitoring and Evaluation (DPME), 2019; Acemoglu et al., 2007).

While there has been an important transfer of stock to Black South Africans, such policies have not reduced inequality of incomes. This raises questions about whether these policies are in fact building empowerment, or are in fact empowering a particular elite, consolidating a preexisting elite, or reproducing the patterns of existing inequality with new actors (recall the increase of intra-group inequality discussed in section two). These possibilities need to be considered against the backdrop of structural factors such as skills shortages and limited access to quality education for poorer people that continue to stall social mobility (Burger \& Jafta, 2010, p. 2). This has brought some analysts to claim that the costs and benefits of this policy cancel each other and are close to zero (Acemoglu et al., 2007, p. 1). While these policies have managed in some cases to allow the ownership of stock, as some citizens got equity in companies in line with Piketty's proposal of participatory socialism (pp. 972-975), it has failed to reduce inequalities.

The important policies related to land redistribution, restitution and tenure are also aimed to correct the dispossession and inequality with regards to land ownership and tenure in South Africa. Nonetheless, their impact has been mixed. While millions of hectares have been redistributed, and thousands of claims of land restoration have been solved, the structure of land ownership seems to have been mostly unaffected. It is also reported that farm workers continue to face higher tenure insecurity and livelihood uncertainty while remaining without control of the land or means of production (Kepe \& Hall, 2018).

These remaining challenges relate to how policies failed to include a consideration of the conditions that create unstable tenure in spaces that reproduce different inequities along gendered, "racial," and ethnic lines (Hall \& Kepe, 2017). They also highlight the role of elites in capturing the policy agenda and policy implementation, thus resulting in the reproduction of the pattern of preexisting inequalities (De Wet, 1997).

\section{5 | RESTATING THE POWER OF CATEGORICAL INEQUALITIES}

We have argued above that a series of well-intentioned policies have not fundamentally reduced economic inequality in South Africa. In this section we suggest that a major reason for this lies in the entrenched nature of categorical divides-especially race-which were established during colonialism and strengthened during apartheid and which are highly obdurate (Tilley \& Shilliam, 2018). This is not something which is adequately understood through income and wealth distributions alone. Although Piketty refers to categorical divisions at various points, 
notably in discussing caste in India, and how such categories can lead to the consolidation of labels that makes the inequality system more resistant to change (2020, p. 304), he does not fully bring out their overarching role in how such categories can reproduce inequities in spite of affirmative action policies, which we have demonstrated here.

In South Africa, important political and budgetary efforts to reduce inequality via different programs and policies since 1994 have not had the expected effects. As Zizzamia et al. (2019) argue in the context of intra-generational mobility, "while social grants and other policies are important in addressing the survival of the chronic poor, they do not address the structural barriers to upward mobility. In this sense, creating opportunities for breaking these structural barriers [remain] imperative for dealing with chronic poverty [and inequality]" (2019, p. 25).

The policies implemented in South Africa have been somewhat successful in reducing perceptions of poverty, the levels of poverty, and the extent of precariousness within poverty. However, the forces that create and reproduce categorical inequalities are dynamic forces that continue to condition, create, and recreate dynamic traps (Stewart \& Langer, 2008; Tilly, 1998); these forces are not necessarily visible as they operate via both institutional and noninstitutional mechanisms, and make it harder for households or individuals to overcome inequality (Pellicer \& Ranchhod, 2016).

A central mechanism that continues to reproduce long-term categorical inequality is spatial segregation. Colonialism and apartheid carved South Africa into four spatially segregated spaces: White dominated commercial farming rural areas; the former impoverished "bantustans" 12 for Blacks; poor urban areas where citizens of color resided (known in South Africa as townships) and where the provision of services and opportunities remained limited; and urban areas where White people had a near exclusive monopoly of property and services. This spatial planning undergirded systemic inequalities in the allocation of education, health, and services. This intentional creation of racial categories compounded by spatial segregation remains extremely effective in producing and reproducing inequities. Recent estimates from Pellicer and Ranchhod (2020) find that being classified as White instead of colored under apartheid raised male incomes by $200 \%$ (on average). It is hardly surprising that South Africa's measured income inequality at the time was among the highest in the world and, most notably, the inequality between racial categories constituted a higher share of aggregate inequality than could be found anywhere else (Bhorat et al., 2001). Post-apartheid policy was expected to overcome this inequality and many policies that are detailed in this paper were put in place to do this. But the momentum of this history weighs heavily and casts a long shadow (see Nelson Mandela Foundation (2018)).

Visually, this is shown most starkly by studies that have used census data to map inequalities in income and many other services across space. Noble et al., (2006) and then, a decade later, David et al. (2018) and Statistics South Africa (2019), show very clearly that the deepest poverty and deprivation in contemporary South Africa remains in the areas that were the "bantustans" and the "townships" under apartheid. Figure 4 shows one example of the inequalities in the incidence of income poverty across South Africa's municipalities. The brown shadings show municipal areas of very high poverty incidence. These municipal clusters accord exactly to previous "bantustans" and "townships." This map and others also make the important point that, even in the better off metropolitan areas of the country, there are inequalities in all dimensions of life, with the worst allocation of services, and opportunities being found in poorer areas that were created and used by apartheid for exploiting South Africans of color.

The persistence of categorical inequalities can only be understood in terms of the specific historical context in which divisions are institutionalized. This is revealed by the complexities of the land reform policies, BEE and other policies in which existing elites and rising elites responded to block, co-opt or undermine policy for their benefit. In South Africa as of 2017, the top 10\% of income earners controlled $65.1 \%$ of the total share of income of the country, and $86.9 \%$ of the total wealth (Piketty, 2015; World Inequality Database (WID), 2020). Such discrepancies in wealth and income creates the conditions in which vested interest groups and elites have the incentives and resources to capture and continue undermining policies that aim to change the structure of inequality within a country.

This raises the importance of the power (or the lack of power) of ideologies in contexts in which new discourses about justice and rights are presented to change existing inequities. Post-apartheid South Africa adopted 


\section{Percentage of the}

population that is income

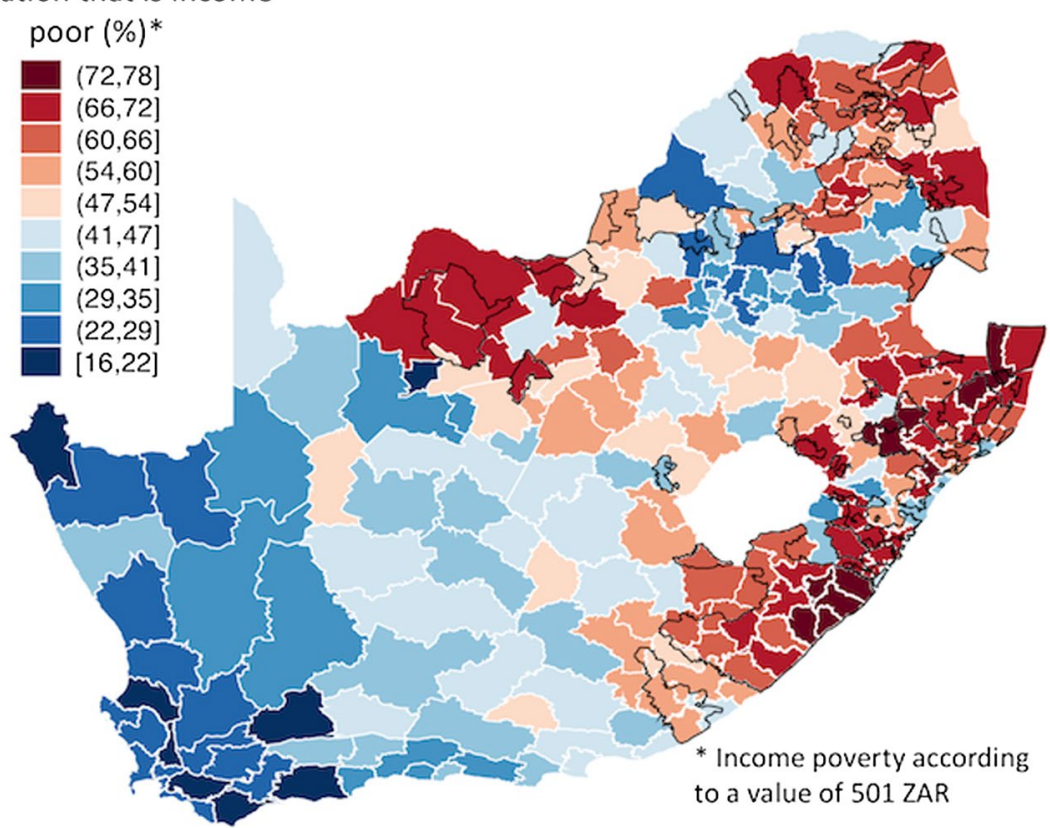

FIG URE 4 Patterns of Poverty across South Africa's Municipalities in 2011. Source: (David, et al., 2018) [Colour figure can be viewed at wileyonlinelibrary.com]

a new discourse about inequality; however, the processes in its economy have remained mostly the same. There is also the possibility of two different usages of ideology with regards to inequality. In the first case, the power of specific sectors commands via overt or covert mechanisms the workings of the state, and in the second case the state continues to have a two track system in which the ideology speaks of redressing gender, racial, and categorical inequalities while the reality of the country goes in a different direction-an ideological cognitive dissonance. South Africa could be a case for analyzing such processes.

These categorical divides reveal how inequality takes place in a "sticky" time dimension. Changes in the structure of inequality are long historical processes, and, therefore, part of a long-term endeavor, a Longue durée. Piketty rightly brings a long-term analysis into describing the forces that create inequality and their changes across time, but he does not fully reckon with long-term legacies and especially the power of colonialism and the relation between capital and power that has long-term repercussions even decades after its ending. This is important to consider given that South Africa seems to illustrate how inequities in capital and wealth remain while shifting its weight from racial to class categories.

Thus, the South African situation makes the case that it is crucial to consider how understanding the interaction of particular categorical inequalities and the role of institutional settings (the political economy) can ground the contextual knowledge for better grounding and evaluating policies aimed to reduce inequalities. More generally, in any context a long-run historical analysis of relevant categorical inequalities will provide a much better-grounded framework of the prevailing social structures and how these constrain the art of the possible looking forward.

\section{6 | CONCLUSION}

In this paper we have reflected on Piketty's arguments in the light of the South African context, an institutional setting that is a hybrid of a middle-income country together with the conditions of a developing country. We have 
emphasized the long-term legacy of South Africa's colonial history, in which a predominantly affluent White population has co-existed with a much larger group of precarious, marginalized, and exploited groups. This situation has not radically changed since the end of apartheid.

While South Africa is an African country, it remains an outlier compared to much of the continent with regards to the trends in inequality and the structure of its economy in relation to most of the rest of the continent (Beegle et al., 2016). Yet, South Africa remains an interesting and important test case for reflecting on the policies suggested by Piketty to reduce inequality. When Piketty gave the Annual Nelson Mandela lecture in South Africa, he tabled six policy proposals for effective rights that should be implemented as a start to confronting inequality in South Africa. These proposals were (2015): (1) A minimum wage, (2) Quality education, (3) Access to property and land, (4) Worker participation in companies' boards, (5) Tax on wealth or inheritance, and 6. International cooperation to deal with tax havens (Piketty, 2015). They all resonate with his policy proposals in Capital and Ideology.

In Section 4 we showed that South Africa has implemented several of these policy suggestions since 1994, in line with the constitutional mandate of empowerment and the achievement of effective rights for its citizens. Yet, these policies have failed to reduce inequality to date. The experiences from these policies illustrate that rights and policy interventions are necessary but not sufficient to reduce inequality. Importantly for Piketty, they point to the fact that ideology, and changes in ideology are necessary, but are not sufficient to reduce deeply entrenched inequalities.

South Africa has implemented policies related to a minimum wage with multi-sectorial minimum wages and a nationwide minimum wage. Such measures have improved the baseline earnings, especially for those at the bottom of the earnings distribution, but they have not affected the driving forces of income and earning inequalities. The country also has increased access to training and education but has struggled much more to improve the quality of the education system for the majority. This inequity continues to reproduce the imprint of the "bantustans," as well as the skill gaps that reinforce earnings and income inequality. In a series of more structural interventions, South Africa has implemented policies related to the redistribution, restitution, and restoration of land, yet these policies have not favored the most vulnerable populations as elites have captured and have skewed policy interventions to favor specific cliques. It has also implemented interesting empowerment initiatives in which Black South Africans have gained participation in companies' boards, yet the representation of workers remains limited, as politically well-connected operators have been given priority in the access to such initiatives. These policies and the structure of the economy have created a thin black elite who is well connected politically rather than a burgeoning black middle class that is required to reduce inequality. This, in turn, limits the scope for redistribution via income tax policy. However, very much in line with Piketty's focus on wealth, there remains scope for improving the redistributive role of tax policy. While income tax policy is progressive, wealth or inheritance has not been part of the tax policy menu or debates until recently even as wealth gains importance as a driver of inequality.

This resonates with the challenges for securing effective rights to a disenfranchised population as access remains different to affordability in South Africa. More citizens are "potentially covered" by public services. But realizing this access often requires being able to afford a service. Affordability of public services remains limited by income, and so a citizen might have access to services but cannot afford to pay for electricity, or the transport and fees to go to a reasonably good school, or hospital. Access to rights remains limited by the workings of a market structure that breeds inequity.

South Africa illustrates that rights are not realities. Rights remain promises that need to be developed and enacted by institutions, policies, and programs that need to account for the barriers that limit the realization of such rights. Understanding how ideology translates into practice remains central to account for how inequality prevails or declines. As of now, the case of South Africa makes it clear that the ideological and political change taking place in 1994 has been insufficient to reduce inequality. The end of apartheid marked a transitional process, a political revolution perhaps, but not yet a revolution in the structure of an economy that breeds difference.

While the promise of representation was brought by the ANC and the tripartite alliance into power, ${ }^{13}$ its symbolic pre-eminence in the transition in 1994 interacted with the effective demobilization of social movements 
(Habib, 2013), and in some cases an adversarial approach toward dissent from within the Tri-Partite alliance itself (McKinley, 2017). Such an approach stifled debates about the divergences between the broad redistributive framing of policy, the actual policy agenda of the early post-apartheid years, and the details of the specific policies themselves. In the views of a number of analysts (see for example Hamilton (2014) and Bond (2014)) the ruling party implemented a narrow, orthodox economic policy agenda by excluding the South African Communist Party and the Congress of South African Trade Unions from discussions of the broad economic policy agenda. This caused considerable antagonism toward the ruling party and its policies which were seen to betray the working class and the commitment to address South Africa's inequalities. Dissenting voices grew louder and protests became more frequent. In some cases, the state responded with repression toward these expressions of discontent, as harshly illustrated by the massacre of miner workers in Marikana. As social movements demobilized, this weakened accountability to broader civil society and allowed new elites to join the existing economic model while ignoring the promises made by the 1996 constitution. The ideology of politics changed with political representation and more equity, but the ideology of the economy did not change in this direction (Bond, 2014, p. 46).

This was not only a South African phenomenon, as the country followed the international trends in the 1990's following the end of the Soviet Union and the "end of history." The ideological shifts that occurred at an international level framed what was possible and "desirable" in South Africa. Because of this, the end of apartheid observed the re-internationalization of South African companies and a greater financialization of the economy, as illustrated by how the share of banking assets controlled by four banks increased form $69 \%$ in 1991 to $84 \%$ in 1995 at the same time as bank branches in poorer areas were closed (Bond, 2014, p. 30). In addition to companies becoming more international, government policies followed mainstream approaches as corporate taxes declined and tax concessions mainly to higher income individuals to incentivize investment (Bond, 2014, p. 265). As the new government was trying to levy the resources for a limping economy, it is understandable that a particular kind of compromise was required, and implementing more transformational policies in a decade in which neoliberalism was the dominant paradigm would have amounted to incentivizing greater capital outflow from the country. It is because of this that it is argued that the policies that were implemented after in 1994 were in fact a social cushion as opposed to effectively redistributive measures (Bond, 2014, p. 99).

Whereas Piketty departs from the assumption that political systems can condition and define the understanding of what is fair and what is not, there remains the possibility that economic interests besets political systems. He acknowledges this political economic reality in both Capital in the 21st Century and in Capital and Ideology and, in the latter argues for the need for to move to new national and international configurations that will bend the will and behavior of the top-end elites to the common good. But, as shown in the South African context, the processes that generate these categorical inequalities embody substantial blockages and resistance in moving toward these democratic solutions.

We have sought to show that a focus on categorical inequalities (Stewart, 2016) can enrich the understanding of the social and economic forces that create inequalities in any context. Such research can enrich the historical understanding of the interaction between local and international forces influencing the discourses related to inequality, and also allow us to distinguish how the different interactions between local structures and international forces create different discursive devices and condition the practice of the policies aimed at reducing inequality.

Ideology is central in reinforcing or changing the discourses and practices on inequality, understanding the ways such ideologies operate in practice in contexts of very high inequality illustrate that the mandates of fairness in a society matter but that the operationalization of such mandates are as important as the ideologies informing such mandates. If we are to break the back of Longue durée inequities, we need to be able to design policies that can break with such inertial forces. South Africa can help us to reflect on the challenges of the operationalization of such policies in the context of categorical inequalities.

\section{DATA AVAILABILITY STATEMENT}

The data that support the findings of this study are openly available in DataFirst at https://www.datafirst.uct. ac.za. 


\section{ORCID}

Murray Leibbrandt (iD https://orcid.org/0000-0003-0829-8844

Michael Savage (iD https://orcid.org/0000-0003-4563-9564

\section{ENDNOTES}

1 In fact, Milanovic also has more recently discovered another spectre which tempers his optimism-that the Asian model of authoritarian capitalism is more effective and productive than the failing liberal meritocratic version found in North America and Europe.

${ }^{2}$ An interesting case for analysis could be the case of Colombia, as recently legal mobilisation has been deployed aiming to influence legislation towards progressive taxation.

3 This estimation is made via the use expenditure data.

4 The summary in the next three paragraphs is based on Leibbrandt et al. (2018).

${ }^{5}$ Some would have been recipients of government grants or have been supported by other household members.

${ }^{6}$ Which starts at a taxable income of ZAR 800,000 per annum.

7 See also Wittenberg (2017a, 2017b, 2017c).

8 This is estimated following the upper-bound poverty line (UBPL). In 2019 the UBPL was ZAR 1.227. For a discussion on how the poverty line is estimated in South Africa see (Budlender et al., 2015).

9 This is important to consider given the evidence that minimum wages did contribute to the reduction of inequality in Latin America (Cornia 2014).

10 Some of the programs implemented by the South African government are the government subsidized housing (RDPs), community residential units, upgrading informal settlements, emergency housing program, subsidized housing program, and the finance linked individual subsidy program.

11 The term "Black" refers to Colored, Indian, and Black South Africans in the 2003 and 2013 acts regulating these policies.

12 The bantustans were territories designed during apartheid which aimed at containing different groups of Black South Africans in something that resembled a rural ghetto, or an indigenous reservation, which aimed to force Black South Africans in these territories.

13 The Tri-Partite alliance, an alliance between the South African Communist Party, the Congress of South African Trade Unions, and the ruling party (ANC).

\section{REFERENCES}

Acemoglu, D., Gelb, S., \& Robinson, J. (2007). Black economic empowerment and economic performance in South Africa. Center for Economic Development Working Papers (pp. 1-36).

Altman, M., Mayer, M., Woolard, I., Du Toit, R., Zuma, K., \& Phakathi, S. (2004). Framework for evaluating the expanded public works programme.

Alvaredo, F., Chancel, L., Piketty, T., Saez, E., \& Zucman, G. (2018). World inequality report 2018. Belknap Press.

Atkinson, A. B. (2014). After Piketty? The British Journal of Sociology, 65(4), 619-638.

Atkinson, A. B., \& Piketty, T. (2007). Top incomes over the twentieth century: A contrast between continental european and english-speaking countries. Oxford University Press.

Ballard, R., Habib, A., \& Valodia, I. (2015). Voices of protest: Social movements in post-apartheid South Africa. University of KwaZulu-Natal Press.

Bassier, I., \& Woolard, I. (2018). Exclusive growth: Rapidly increasing top incomes amidst low national growth in South Africa. REDI3x3 Working Paper (pp. 1-31).

Beegle, K., Christiaensen, L., Dabalen, A., \& Gaddis, I. (2016). Poverty in a rising Africa. The World Bank.

Bhorat, H., Kanbur, R., \& Stanwix, B. (2014). Estimating the impact of minimum wages on employment, wages, and nonwage benefits: The case of agriculture in South Africa. American Journal of Agricultural Economics, 96(5), $1402-1419$.

Bhorat, H., Leibbrandt, M., \& Maziya, M. (2001). Fighting poverty: Labour markets and inequality. University of Cape Town Press.

Bond, P. (2014). Elite transition: From apartheid to neoliberalism in South Africa. Pluto press.

Bourguignon, F. (2017). The globalization of inequality. Princeton University Press. 
Budlender, J., Leibbrandt, M., \& Woolard, I. (2015, August). South African poverty lines: A review and two new money-metric thresholds. Southern Africa Labour and Development Research Unit (SALDRU) Working Papers (pp. 1-46).

Burger, R., \& Jafta, R. (2010). Affirmative action in South Africa: An empirical assessment of the impact on labour market outcomes. Centre for Research on Inequality, Human Security and Ethnicity (CRISE) (pp. 1-26).

Chancel, L., Cogneau, D., Gethin, A., \& Myczkowski, A. (2019, October). How large are African inequalities? Towards Distributional National Accounts in Africa, 1990-2017. World Inequality Database (WID) Working Papers (pp. 1-71).

Chatterjee, A., Czajka, L., \& Gethin, A. (2020, April). Estimating the distribution of household wealth in South Africa. UN WIDER Working Paper Series (pp. 1-51).

Cornia, G. A. (Ed.). (2014). Falling inequality in Latin America: Policy changes and lessons. Oxford University Press.

Daniels, R. C. (2001). Modeling vulnerability to over-indebtedness among urban indebted households in South Africa. Johannesburg, DPRU/FES conference on Labour Markets and Poverty (pp. 1-19).

David, A., Guilbert, N., Hamaguchi, N., Higashi, Y., Hino, H., Leibbrandt, M., \& Shifa, M. (2018, January). Spatial poverty and inequality in South Africa: A municipality level analysis. SALDRU Working Paper (pp. 1-39).

De Wet, C. (1997). Land reform in South Africa: A vehicle for justice and reconciliation, or a source of further inequality and conflict? Development Southern Africa, 14(3), 355-362.

. Department of Planning, Monitoring and Evaluation (DPME). (2019). Towards a 25 year review 1994-2015. Department of Planning, Monitoring and Evaluation (DPME).

Dinkelman, T., \& Ranchhod, V. (2012). Evidence on the impact of minimum wage laws in an informal sector: Domestic workers in South Africa. Journal of Development Economics, 99(1), 27-45.

Finn, A., \& Leibbrandt, M. (2018, August). The evolution and determination of earnings inequality in post-apartheid South Africa. UN-WIDER Working Papers (pp. 1-38).

Finn, A., Leibbrandt, M., \& Ranchhod, V. (2016, August). Patterns of persistence: Intergenerational mobility and education in South Africa. SALDRU Working Papers (pp. 1-37).

Habib, A. (2013). South Africa's suspended revolution: Hopes and prospects. Ohio University Press.

Hall, R., \& Kepe, T. (2017). Elite capture and state neglect: New evidence on South Africa's land reform. Review of African Political Economy, 44(151), 122-130.

Hamilton, L. (2014). Are South Africans Free? Bloomsbury Publishing.

Hawthorne, R., Goga, S., Sihin, R., \& Robb, G. (2014). Centre for competition, regulation and economic development.

Hino, H., Langer, A., Lonsdale, J., \& Stewart, F. (2019). From divided pasts to cohesive futures: Reflections on Africa. Cambridge University Press.

Hlatshwayo, M. S. (2017). The expanded public works programme: Perspectives of direct beneficiaries. The Journal for Transdisciplinary Research in Southern Africa, 13(1), 1-8.

Hundenborn, J., Leibbrandt, M., \& Woolard, I. (2018, December). Drivers of inequality in South Africa. UNU WIDER Working Paper (pp. 1-24).

Inchauste, G., Lustig, N., Maboshe, M., Purfield, C., \& Woolard, I. (2015, February). The distributional impact of fiscal policy in South Africa. World Bank Working Papers (pp. 1-50).

Kepe, T., \& Hall, R. (2018). Land redistribution in South Africa: Towards decolonisation or recolonisation? Politikon, 45(1), 128-137.

Krugman, P., \& Venables, A. J. (1995). Globalization and the inequality of nations. The Quarterly Journal of Economics, 110(4), 857-880.

Leibbrandt, M., Finn, A., \& Woolard, I. (2012). Describing and decomposing post-apartheid income inequality in South Africa. Development Southern Africa, 29(1), 19-34.

Leibbrandt, M., Ranchhod, V., \& Green, P. (2018, December). Taking stock of South African income inequality. UNUWIDER Working Papers (pp. 1-23).

Leibbrandt, M., Woolard, I., Finn, A., \& Argen, J. (2010, May 28). Trends in South African income distribution and poverty since the fall of apartheid. OECD Social, Employment and Migration Working Papers (pp. 1093).

Lemanski, C. (2017). Citizens in the middle class: The interstitial policy spaces of South Africa's housing gap. Geoforum, 79, 101-110.

Lundberg, S., \& Startz, R. (1998). On the persistence of racial inequality. Journal of Labor Economics, 16(2), $292-323$.

Lustig, N., Lopez-Calva, L. F., \& Ortiz-Juarez, E. (2012). Declining inequality in Latin America in the 2000s: The cases of Argentina, Brazil, and Mexico. The World Bank.

Mashekwa, M., \& Woolard, I. (2018, August). Revisiting the impact of direct taxes and transfers on poverty and inequality in South Africa. WIDER Working Paper (pp. 1-31).

McKinley, D. T. (2017). South Africa's corporatised liberation: A critical analysis of the ANC in power. Jacana.

Milanovic, B. (2016). Global inequality: A new approach for the age of globalization. Harvard University Press.

Narayan, A., Van der Weide, R., Cojocaru, A., Lakner, C., Redaelli, S., Gerszon, M. D., Gupta, R., Ramasubbaiah, N., \& Thewissen, S. (2018). Fair progress?: Economic mobility across generations around the world. World Bank. 
Nelson Mandela Foundation. (2018). Mandela Initiative (2018). Grappling with Poverty and Inequality: A Report on the Processes and Findings of the Mandela Initiative. Author.

Noble, M., Babita, M., Barnes, H., Dibben, C., Magasela, W., Noble, S., Ntshongwana, P., Phillips, H., Rama, S., Roberts, B., Wright, G., \& Zungu, S. (2006). The provincial indices of multiple deprivation for South Africa 2001. Centre for the Analysis of South African Social Policy.

Odusola, A. F., Cornia, G. A., Bhorat, H., \& Conceição, P. (2017). Income inequality trends in sub-Saharan Africa: Divergence, determinants ad consequences. United Nations Development Programme, Regional Bureau for Africa.

Orthofer, A. (2016). Savings and wealth in the context of extreme inequality. Stellenbosch University.

Pellicer, M., \& Ranchhod, V. (2016). Inequality traps and human capital accumulation in South Africa. In A. Black (Ed.), Employment intensive growth in South Africa (pp. 126-153). UCT Press.

Pellicer, M., \& Ranchhod, V. (2020, February). Estimating the effect of racial classification on labour market outcomes: A case study from Apartheid South Africa. SALDRU Working Papers (pp. 1-38).

Pellicer, M., Ranchhod, V., Sarr, M., \& Wegner, E. (2011, March). Inequality traps in South Africa: An overview and research agenda. SALDRU Working Papers (pp. 1-61).

Piketty, T. (2014). Capital in the twenty-first century. Harvard University Press.

Piketty, T. (2015). Transcript of Nelson Mandela Annual Lecture 2015.

Piketty, T. (2020). Capital and ideology. Harvard University Press.

Piketty, T., \& Saez, E. (2003). Income inequality in the United States, 1913-1998. The Quarterly Journal of Economics, 118(1), 1-41.

Piraino, P. (2015). Intergenerational earnings mobility and equality of opportunity in South Africa. World Development, 67, 396-405.

Scheidel, W. (2018). The great leveler: Violence and the history of inequality from the stone age to the twenty-first century. Princeton University Press.

Schotte, S., Zizzamia, R., \& Leibbrandt, M. (2018). A poverty dynamics approach to social stratification: The South African case. World Development, 110, 88-103.

Simson, R., \& Savage, M. (2020). The global significance of national inequality decline. Third World Quarterly, 41(1), $20-41$.

Sisulu, L. (2014). Budget vote speech by Minister of Human Settlements.

South African Government. (2019). Expanded Public Works Programme.

Southern African Catholic Bishops' Conference. (2017). RDP Housing: Success or Failure?

Spaull, N., \& Jansen, J. D. (2019). South African schooling: The enigma of inequality. Springer.

Statistics South Africa. (2019). Inequality trends in South Africa: A multidimensional diagnostic of inequality. Statistics South Africa.

Stewart, F. (2016). Changing perspectives on inequality and development. Studies in Comparative International Development, 51(1), 60-80.

Stewart, F., \& A. Langer (Eds.) (2008). Horizontal inequalities and conflict: Understanding group violence in multiethnic societies. Palgrave.

Tilley, L., \& Shilliam, R. (2018). Raced markets: An introduction. New Political Economy, 23(4), 534-543.

Tilly, C. (1998). Durable inequality. University of California Press.

Wilkinson, R., \& Pickett, K. (2010). The spirit level. Why equality is better for everyone. Penguin.

Wittenberg, M. (2017a, October 2). Measurement of earnings: Comparing South African tax and survey data. Research Project on Employment, Income Distribution and Inclusive Growth (REDI3x3) Working Papers (pp. 1-22).

Wittenberg, M. (2017b). Wages and wage inequality in South Africa 1994-2011: Part 1-Wage measurement and trends. South African Journal of Economics, 85(2), 279-297.

Wittenberg, M. (2017c). Wages and wage inequality in South Africa 1994-2011: Part 2-Inequality measurement and trends. South African Journal of Economics, 85(2), 298-318.

Woolard, I., \& Leibbrandt, M. (2013). The evolution and impact of unconditional cash transfers in South Africa. In C. Sepúlveda, A. Harrison, \& J. Y. Lin (Eds.), Annual World Bank Conference on Development Economics 2011: Development Challenges in a Post-crisis World (pp. 363-384). World Bank.

World Inequality Database (WID). (2020). World Inequality Database (WID).

Zizzamia, R., Schotte, S., \& Leibbrandt, M. (2019, March). Snakes and ladders and loaded dice: Poverty dynamics and inequality in South Africa, 2008-2017. UNU WIDER Working Paper (pp. 1-30).

How to cite this article: Díaz Pabón FA, Leibbrandt M, Ranchhod V, Savage M. Piketty comes to South Africa. Br J Sociol. 2021;72:106-124. https://doi.org/10.1111/1468-4446.12808 